\title{
○
}

\section{EUROPEAN MEDICINES AGENCY}

S C I E N C E E D I CINES H EALTH

6 May 2019

EMADOC-628903358-645

\section{Public summary of opinion on orphan designation 4-hydroxy-6-\{2-[4-(trifluoromethyl)phenyl]ethyl\}pyridazin-3(2H)-one for the treatment of Friedreich's ataxia}

On 1 April 2019, orphan designation (EU/3/19/2148) was granted by the European Commission to Takeda Pharma A/S, Denmark, for 4-hydroxy-6-\{2-[4-(trifluoromethyl)phenyl]ethyl\}pyridazin-3(2H)one (also known as TAK-831) for the treatment of Friedreich's ataxia.

\section{What is Friedreich's ataxia?}

Friedreich's ataxia is an inherited disease that causes a range of symptoms that worsen over time, including difficulty walking, inability to co-ordinate movements, muscle weakness, speech problems, damage to the heart muscle and diabetes.

Patients with Friedreich's ataxia do not have enough frataxin, a protein that regulates iron in mitochondria (energy-producing components of cells). As a result, iron builds up within the cells, which in turn results in the production of toxic forms of oxygen that damage cells in the brain, the spinal cord and nerves, as well as in the heart and pancreas.

Friedreich's ataxia is a debilitating and life-threatening disease because of the worsening of symptoms over time. The disease is usually fatal in early adulthood.

\section{What is the estimated number of patients affected by the condition?}

At the time of designation, Friedreich's ataxia affected approximately 0.5 in 10,000 people in the European Union (EU). This was equivalent to a total of around 26,000 people*, and is below the ceiling for orphan designation, which is 5 people in 10,000 . This is based on the information provided by the sponsor and the knowledge of the Committee for Orphan Medicinal Products (COMP).

\section{What treatments are available?}

At the time of designation, no satisfactory methods were authorised in the EU for the treatment of Friedreich's ataxia. Different treatments were used to relieve the symptoms of the disease, such as medicines for diabetes and heart problems. Patients were also offered walking aids to allow them to

*Disclaimer: For the purpose of the designation, the number of patients affected by the condition is estimated and assessed on the basis of data from the European Union (EU 28), Norway, Iceland and Liechtenstein. This represents a population of $518,400,000$ (Eurostat 2019). 
remain as independent as possible, and other devices to assist them with everyday tasks such as eating and taking care of themselves. Speech therapy and physiotherapy were also used.

\section{How is this medicine expected to work?}

The medicine works by blocking an enzyme called D-amino acid oxidase (DAAO), which leads to increased levels of a substance known as D-serine in various organs and tissues, in particular in the brain. In the brain, D-serine is thought to play a key role in controlling muscle activity. By increasing the levels of D-serine, the medicine is expected to improve coordination of movements.

\section{What is the stage of development of this medicine?}

The effects of the medicine have been evaluated in experimental models.

At the time of submission of the application for orphan designation, clinical trials with the medicine in patients with Friedreich's ataxia were ongoing.

At the time of submission, the medicine was not authorised anywhere in the EU for Friedreich's ataxia. Orphan designation of the medicine had been granted in the United States for this condition.

In accordance with Regulation (EC) No 141/2000 of 16 December 1999, the COMP adopted a positive opinion on 21 February 2019 recommending the granting of this designation.

Opinions on orphan medicinal product designations are based on the following three criteria:

- the seriousness of the condition;

- the existence of alternative methods of diagnosis, prevention or treatment;

- either the rarity of the condition (affecting not more than 5 in 10,000 people in the EU) or insufficient returns on investment.

Designated orphan medicinal products are products that are still under investigation and are considered for orphan designation on the basis of potential activity. An orphan designation is not a marketing authorisation. As a consequence, demonstration of quality, safety and efficacy is necessary before a product can be granted a marketing authorisation.

\section{For more information}

Sponsor's contact details:

Contact details of the current sponsor for this orphan designation can be found on the EMA website.

For contact details of patients' organisations whose activities are targeted at rare diseases see:

- Orphanet, a database containing information on rare diseases, which includes a directory of patients' organisations registered in Europe; 
- European Organisation for Rare Diseases (EURORDIS), a non-governmental alliance of patient organisations and individuals active in the field of rare diseases. 
Translations of the active ingredient and indication in all official EU languages ${ }^{1}$, Norwegian and Icelandic

\begin{tabular}{|c|c|c|}
\hline Language & Active ingredient & Indication \\
\hline English & $\begin{array}{l}\text { 4-hydroxy-6-\{2-[4- } \\
\text { (trifluoromethyl)phenyl]ethyl\}pyridazin-3(2H)- } \\
\text { one }\end{array}$ & Treatment of Friedreich's ataxia \\
\hline Bulgarian & $\begin{array}{l}\text { 4-хидрокси-6-\{2-[4- } \\
\text { (трифлуорометил)фенил]етил\}пиридазин- } \\
\text { 3(2Н)-он }\end{array}$ & Лечение на атаксия на Фридрайх \\
\hline Croatian & $\begin{array}{l}\text { 4-hidroksi-6- }\{2-[4- \\
\text { (trifluorometil)fenil]etil\}piridazin-3(2H)-on }\end{array}$ & Liječenje Friedreichove ataksije \\
\hline Czech & $\begin{array}{l}\text { 4-hydroxy-6- }\{2-[4- \\
\text { (trifluoromethyl)fenyl]ethyl }\} \text { pyridazin-3(2H)-on }\end{array}$ & Léčba Friedrichovy ataxie \\
\hline Danish & $\begin{array}{l}\text { 4-hydroxy-6- }\{2-[4- \\
\text { (trifluormethyl)phenyl] ethyl }\} \text { pyridazin-3(2H)-on }\end{array}$ & Behandling af Friedreichs ataksi \\
\hline Dutch & $\begin{array}{l}\text { 4-hydroxy-6- }\{2-[4- \\
\text { (trifluoromethyl)fenyl]ethyl }\} \text { pyridazine-3(2H)-on }\end{array}$ & $\begin{array}{l}\text { Behandeling van de ataxie van } \\
\text { Friedreich }\end{array}$ \\
\hline Estonian & $\begin{array}{l}\text { 4-hüdroksü-6-\{2-[4- } \\
\text { (trifluorometüül)fenüül]etüül\}püridasiin-3(2H)- } \\
\text { üks }\end{array}$ & Friedreichi ataksia ravi \\
\hline Finnish & $\begin{array}{l}\text { 4-hydroksi-6- }\{2-[4- \\
\text { (trifluorometyyli)fenyyli]etyyli }\} \text { pyridatsiini- } \\
3(2 \mathrm{H}) \text {-oni }\end{array}$ & Friedreichin ataksian hoito \\
\hline French & $\begin{array}{l}\text { 4-hydroxy-6-\{2-[4- } \\
\text { (trifluorométhyl)phényl]éthyl\}pyridazine-3(2H)- } \\
\text { one }\end{array}$ & Traitement de I'ataxie de Friedreich \\
\hline German & $\begin{array}{l}\text { 4-Hydroxy-6- }\{2-[4- \\
\text { (trifluoromethyl)phenyl]ethyl\}pyridazin-3(2H)- } \\
\text { on }\end{array}$ & Therapie der Friedreichschen Ataxie \\
\hline Greek & 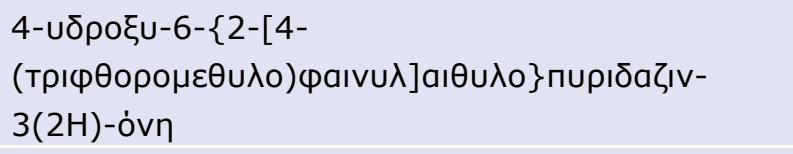 & 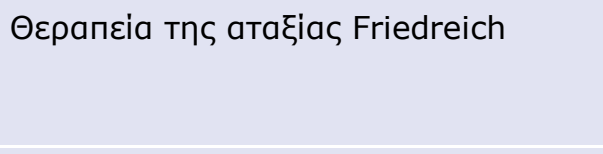 \\
\hline Hungarian & $\begin{array}{l}\text { 4-hidroxi-6- }\{2-[4- \\
\text { (trifluormetil)fenil]etil\}piridazin-3(2H)-on }\end{array}$ & Friedreich ataxia kezelése \\
\hline Italian & $\begin{array}{l}\text { 4-idrossi-6- }\{2-[4- \\
\text { (trifluorometil)fenil]etil\}piridazin-3(2H)-one }\end{array}$ & Trattamento dell'atassia di Friedreich \\
\hline Latvian & $\begin{array}{l}\text { 4-hidroksi-6- }\{2-[4- \\
\text { (trifluorometil)fenil]etil\}piridazīn-3(2H)-ons }\end{array}$ & Frīdreiha ataksijas ārstēšana \\
\hline Lithuanian & $\begin{array}{l}\text { 4-hidroksi-6- }\{2-[4- \\
\text { (trifluorometil)fenil]etil\}piridazin-3(2H)-onas }\end{array}$ & Fridreicho ataksijos gydymas \\
\hline Maltese & $\begin{array}{l}\text { 4-idrossi-6- }\{2-[4- \\
\text { (trifluworometil)fenil]etil\}piridażina-3(2H)-one }\end{array}$ & Kura tal-atassja ta' Friedreich \\
\hline Polish & $\begin{array}{l}\text { 4-hydroksy-6- }\{2-[4- \\
\text { (trifluorometylo)fenylo]etylo }\}-3(2 \mathrm{H})- \\
\text { pirydazynon }\end{array}$ & Leczenie ataksji Friedreicha \\
\hline
\end{tabular}

\footnotetext{
${ }^{1}$ At the time of designation
} 


\begin{tabular}{|c|c|c|}
\hline Language & Active ingredient & Indication \\
\hline Portuguese & $\begin{array}{l}\text { 4-hidroxi-6- }\{2-[4- \\
\text { (trifluorometil)fenil]etil\}piridazin-3(2H)-ona }\end{array}$ & Tratamento da ataxia de Friedreich \\
\hline Romanian & $\begin{array}{l}\text { 4-hidroxi-6- }\{2-[4- \\
\text { (trifluorometil)fenil]etil\}piridazin-3(2H)-onă }\end{array}$ & Tratamentul ataxiei Friedreich \\
\hline Slovak & $\begin{array}{l}\text { 4-hydroxy-6-\{2-[4- } \\
\text { (trifluórometyl)fenyl]etyl\}pyridazín-3(2H)-ón }\end{array}$ & Liečba Friedreichovej ataxie \\
\hline Slovenian & $\begin{array}{l}\text { 4-hidroksi-6- }\{2-[4- \\
\text { (trifluorometil)fenil]etil\}piridazin-3(2H)-on }\end{array}$ & Zdravljenje Friedreichove ataksije \\
\hline Spanish & $\begin{array}{l}\text { 4-hidroxi-6- }\{2-[4- \\
\text { (trifluorometil)fenil]etil }\} \text { piridacina- } 3(2 \mathrm{H}) \text {-ona }\end{array}$ & Tratamiento de la ataxia de Friedreich \\
\hline Swedish & $\begin{array}{l}\text { 4-hydroxi-6- }\{2-[4- \\
\text { (trifluormetyl)fenyl]etyl\}pyridazin-3(2H)-on }\end{array}$ & Behandling av Friedreichs ataxi \\
\hline Norwegian & $\begin{array}{l}\text { 4-hydroksy-6- }\{2-[4- \\
\text { (trifluormetyl)fenyl]etyl\}pyridazin-3(2H)-on }\end{array}$ & Behandling av Friedreichs ataksi \\
\hline Icelandic & $\begin{array}{l}\text { 4-hýdroxý-6-\{2-[4- } \\
\text { (tríflúormetýl)fenýl]etýl\}pýrídasín-3(2H)-ón }\end{array}$ & Meðferð arfgengs mænuslingurs \\
\hline
\end{tabular}

